\title{
Simulation of the process of short-term forecasting of the 25.03.2020 Onekotan tsunami
}

\author{
Yury P. Korolev* \\ Pavel Yu. Korolev
}

\author{
Institute of Marine Geology and Geophysics, FEB RAS, \\ Yuzhno-Sakhalinsk, Russia \\ *E-mail:Yu_P_K@mail.ru
}

\begin{abstract}
Peзюме RUS
This work aims to demonstrate the potential application of the data from the DART 21416 operation station and the DART 21402 virtual station for the short-term forecast of the 2020 Onekotan tsunami in the localities of the Kuril Islands. The retrospective assessment has been made using the method (express-method) of a short-term tsunami forecast. The forecast lead time according to the virtual DART 21402 station is higher in comparison with the data of DART 21416 station. It is $41 \mathrm{~min}$ for Severo-Kurilsk and more than $60 \mathrm{~min}$ for other settlements of the Kuril Islands. The estimated amplitudes of the tsunami were $30 \mathrm{~cm}$ nearby the water's edge in Severo-Kurilsk, and up to $4 \mathrm{~cm}$ in other settlements of the Kuril Islands. When implemented, the express-method may be a more effective means of real-time tsunami forecasting than the method of the Japanese Meteorological Agency, according to which the waves with amplitudes of 1-3 m have been expected at the Kuril Islands, while the actual amplitudes have reached just $0.5 \mathrm{~m}$.
\end{abstract}

\section{Keywords}

tsunami, earthquake magnitude, tsunami alarm, Onekotan, Kuril Islands, Severo-Kurilsk, real-time tsunami forecast, forecast lead time, DART

For citation: Korolev Yu.P., Korolev P.Yu. Simulation of the process of short-term forecasting of the 25.03.2020 Onekotan tsunami. Geosistemy perekhodnykh zon = Geosystems of Transition Zones, 2020, vol. 4, no. 2, pp. $259-265$. (In Russ.). https://doi.org/10.30730/gtrz.2020.4.2.259-265

Для цитирования: Королев Ю.П., Королев П.Ю. Моделирование процесса оперативного прогнозирования Онекотанского цунами 25.03.2020. Геосистемы переходных зон, 2020, т. 4, № 2, с. 259-265.

https://doi.org/10.30730/gtrz.2020.4.2.259-265

\section{References}

1. Korolev Yu. 2012. A new approach to short-term tsunami forecasting. Tsunami-Analysis of a Hazard-From Physical Interpretation to Human Impact (Ed. Gloria I. Lopez). Rijeka, Croatia: InTech, 141-180. dx.doi.org/10.5772/2614

2. National Centers for Environmental Information. URL: https://www.ngdc.noaa.gov/hazard/tsu_db.shtml (accessed 4.04.2020).

3. National Data Buoy Center. URL: https://ndbc.noaa.gov/dart.shtml (accessed 25.03.2020).

4. NOAA Center for Tsunami Research. URL: http://nctr.pmel.noaa.gov/Dart (accessed 25.03.2020).

5. Ob ugroze tsunami posle zemletriaseniia u poberezh'ia Severo-Kuril'skogo raiona 25 marta 2020 goda [On the threat of tsunamis after an earthquake off the coast of the North Kuril region on March 25, 2020]. URL: http://sakhugms.ru/index.php/o-nas/strutura/tsentr-tsunami (accessed 8.04.2020).

6. Rossiiskaia sluzhba preduprezhdeniia o tsunami [Russian tsunami warning service]. URL: http://rtws.ru/sea-level/ (accessed 8.04.2020).

7. Users Guide for the Pacific Tsunami Warning Center Enhanced Products for the Pacific Tsunami Warning System. 2014. IOC Technical Series, 105 (UNESCO/IOC). 